\title{
COMPUTAÇÃO GRÁFICA
}

I.S.Oliveira

"UMA IMAGEM PODE VALER MIL PALAVRAS..."

"Ela é a pura representação visual da matemática." Assim define o professor George Francis, do Departamento de Matemática da Universidade de Illinois, a computação gráfica. Hoje, essa técnica está em todo lugar: nos canais de televisão, nos comerciais em que se vêem frutas dançando e pastas de dente cantando, e nos monitores de computadores dos laboratórios cientificos e industriais de todo o mundo. E até mesmo em capas de revistas.

Mas como trabalha um computador gráfico? Uma tela de um monitor de computador, assim como a de um aparelho de TV, é composta de muitos milhares de pequenos pontos que acendem e apagam várias dezenas de vezes por segundo. Há dez anos, um programador tinha de escrever uma longa lista de instruções para que cada ponto acendesse ou apagasse. Agora, graças a equipamentos muito mais rápidos, como os supercomputadores, um artista pode transformar uma série de pontos vermelhos em uma linha vermelha na mesma velocidade que faria caso a traçasse com uma caneta ou um pincel. Hoje, quase todos os produtos lançados no mercado são concebidos, desenhados e testados num computador antes de entrar na linha de produção. Também os cientistas podem "enxergar" o interior de moléculas e alterar sua composição com o auxilio de uma realidade artificial criada nas telas dos computadores. 0 mesmo pode ser feito por aqueles que estudam uma estrela que está morrendo ou uma explosão nuclear. $\mathrm{O}$ olho, assim, pode ir a lugares onde nenhum ser vivo conseguiria.

Um bom exemplo dessa poderosa ferramenta, pode ser lembrado pela explosão do ônibus espacial Challenger. Com a computação gráfica foi possível reproduzir os anéis de vedação dos tanques de combustível de acordo com suas características matemáticas. Examinando as imagens geradas, os engenheiros puderam ver claramente como os anéis falharam sob temperaturas muito frias, causando a catástrofe. Nos últimos seis anos, a computação gráfica cresceu significativamente nos Estados Unidos, Europa e Japão.

A compugrafia engloba todos os métodos e técnicas relacionados com a conversão de dados de (e para) dispositivos gráficos, através do computador. Logo, qualquer aplicação computacional que engloba imagens utiliza técnicas compugráficas.

Seção de Informática, Instituto de Geociências, USP. 


\section{CAD \& CAM}

O CAD-CAM (Computer-Aided Design - Computer-Aided Manufacturing) já é o melhor instrumento para engenheiros e arquitetos industriais projetarem desde móveis até prédios. Por meio desta técnica, um cliente pode observar não apenas como o novo produto ficará como também se certificar de sua qualidade e resistência.

O CAD pode ser utilizado para criação de um modelo visual de um objeto imaginado. Olhando um objeto em três dimensões, você pode ter a sensação de que ele é real. Isso facilita muito, na hora de tomar decisões sobre os conceitos reais do desenho, como por exemplo, no momento de escolher um tipo de pilar num projeto arquitetônico.

\section{SDG - Sistema para digitalização de Gráficos}

Não se pode negar que as pessoas que trabalham com mapas, gráficos, desenhos e outros tipos de representação gráficas enfrentam problemas com o armazenamento e atualização de seus documentos.

Os cálculos feitos a partir desses gráficos podem ser, por vezes, trabalhosos, demorados e suscetíveis a erros, conforme o procedimento adotado. Por exemplo, cálculos de áreas teriam que ser feitos com o auxilio de planígrafos ou então com o levantamento de coordenadas seguido de uma interaão. Da mesma forma, o cálculo de perímetro enfrentaria problemas bastante parecidos.

O SDG, Sistema de Digitalização de Dados Gráficos, reduz sensivelmente estas dificuldades. Com o SDG, os gráficos são digitalizados e os dados colhidos são armazenados em disquetes num arquivo padrão. $\mathrm{O}$ sistema tem ainda a capacidade de calcular áreas e perímetros de quaisquer trechos de um gráfico. O sistema é composto por um microcomputador tipo IBM-AT de 32 bits, uma mesa digitalizadora, uma impressora e opcionalmente, um ploter.

A interação Usuário-Sistema é bastante simples.

Com tais características, o SDG pode ser aplicado a vários campos: digitalização de curvas estatísticas, dados cartográficos, cálculos de área e perímetro e análises qualitativas de curvas.

\section{MAPEAMENTO GEOLÓGICO DIGITALIZADO}

A elaboração de mapas geológicos, mapas de cavernas e mapas cartográficos em geral, tem sido bastante explorada por alguns técnicos e docentes do Instituto de Geociências da USP, através de programas de CAD que possibilitam a digitalização desses mapas. $O$ resultado tem sido satisfatório.

Utilizando uma estação gráfica de trabalho, baseada num microcomputador 
compatível com IBM PC AT 486, uma mesa digitalizadora e um plotter, a seção de Informática do IGc conta com um desenhista especializado em CAD, o qual executa os desenhos solicitados pelos docentes para apresentações em palestras, congressos, feiras e teses.

O programa utilizado tem sido basicamente o AutoCAD versão 12. 